\title{
Horizontal and Vertical Emissions of Carbon Dioxide and Methane from a Tropical Peat Soil Cultivated with Pineapple (Ananas comosus (L.) Merr.)
}

\author{
Alicia Vanessa Jeffary ${ }^{1}$, Ahmed Osumanu Haruna ${ }^{1,2,3}$, Roland Kueh Jui Heng ${ }^{4}$, Liza Nuriati Lim Kim Choo ${ }^{1,5}$ \& \\ Latifah Omar ${ }^{1}$ \\ ${ }^{1}$ Department of Crop Science, Faculty of Agriculture and Food Sciences, Universiti Putra Malaysia (UPM), \\ Bintulu Campus, Bintulu, Sarawak, Malaysia \\ ${ }^{2}$ Institute of Tropical Agriculture and Food Security, Universiti Putra Malaysia, Serdang, Selangor Darul Ehsan, \\ Malaysia \\ ${ }^{3}$ Center of Excellence in Borneo Ecosystem Science Research (Borneo Ekosains), Faculty of Agriculture and \\ Food Sciences, Universiti Putra Malaysia (UPM), Bintulu Campus, Bintulu, Sarawak, Malaysia \\ ${ }^{4}$ Department of Forestry Science, Faculty of Agriculture and Food Sciences, Universiti Putra Malaysia (UPM), \\ Bintulu Campus, Bintulu, Sarawak, Malaysia \\ ${ }^{5}$ Malaysian Agricultural Research and Development Institute (MARDI), Roban, Saratok, Sarawak, Malaysia \\ Correspondence: Ahmed Osumanu Haruna, Department of Crop Science, Faculty of Agriculture and Food \\ Sciences, Universiti Putra Malaysia (UPM), Bintulu Campus, Bintulu, Sarawak, Malaysia. E-mail: \\ osumanuharuna@gmail.com
}

\author{
Received: December 14, 2018 Accepted: January 4, 2019 Online Published: May 14, 2019 \\ doi:10.5539/sar.v8n3p1 \\ URL: https://doi.org/10.5539/sar.v8n3p1
}

\begin{abstract}
Peat soils have been developed for large scale plantations such as oil palm due to their positive contribution to Malaysia's economic growth in agriculture sector. However, these developments contribute to the emissions of greenhouse gases (GHGs) mainly carbon $\left(\mathrm{CO}_{2}\right)$ and methane $\left(\mathrm{CH}_{4}\right)$. To date, there were limited information of GHGs emissions from pineapple cultivation and also inadequate data on horizontally and vertically soil GHGs emissions in peat soil profile. Thus, this study was carried out to determine carbon $\mathrm{CO}_{2}$ and $\mathrm{CH}_{4}$ emissions horizontally and vertically from a drained tropical peat soils from a drained tropical peat soils cultivated with pineapple (Ananas comosus (L.) Merr. Horizontal and vertical movements of $\mathrm{CO}_{2}$ and $\mathrm{CH}_{4}$ were measured from a drained tropical peatland with Ananas comosus (L.) Merr. Tropical peat soils cultivated with Ananas comosus (L.) Merr. contributed to $79.7 \%$ of $\mathrm{CO}_{2}$, and $0.2 \%$ of $\mathrm{CH}_{4}$ based on the yearly basis regardless of the differences in diurnal transportation; horizontal and vertical emission. Soil $\mathrm{CO}_{2}$ and $\mathrm{CH}_{4}$ were emitted the most through horizontal transportation with $70.84 \% \mathrm{CO}_{2}$, and $0.19 \% \mathrm{CH}_{4}$ compared to $8.85 \% \mathrm{CO}_{2}$, and $0.02 \% \mathrm{CH}_{4}$ in vertical transportation. The emission of $\mathrm{CO}_{2}$ was influenced by depth of water table and temperature. It is generally believed that lowering of peats water table leads to emission of higher $\mathrm{CO}_{2}$ emission because this process leads to exposure of peat soils to oxidation. Seasonal variation in $\mathrm{CH}_{4}$ flux was higher in the wet seasons due to rainfall; this might have increased the water table of the peat soil. The results suggest that $\mathrm{CO}_{2}$ and $\mathrm{CH}_{4}$ emissions occur both horizontally and vertically regardless of season. Therefore in order not to underestimate $\mathrm{CO}_{2}$ and $\mathrm{CH}_{4}$ emissions from peat soil, it is important to measure the emissions of this greenhouse gas which has been implicated in environmental pollution horizontally and vertically.
\end{abstract}

Key words: carbon dioxide, horizontal, methane, peatlands, vertical

\section{Introduction}

Cultivation of pineapples on peat soils is economically profitable. However, concerns have been expressed about cultivation of crops on peat soils as they are prone to emissions of harmful greenhouse gases such as carbon dioxide $\left(\mathrm{CO}_{2}\right)$ and methane $\left(\mathrm{CH}_{4}\right)$. A study on pineapple cultivation on a peat soil had revealed that $\mathrm{CO}_{2}$ and $\mathrm{CH}_{4}$ are emitted (Liza, 2014). Globally, agriculture contributes to $24 \%$ of the greenhouse gases emission (IPCC, 2014). Tropical peatlands with high organic matter content are naturally a conducive environment for greenhouse 
gas emissions especially when they are cultivated. Methane as an example, can be consumed by aerobic microbes as it moves to the soil surface.

Carbon dioxide and $\mathrm{CH}_{4}$ are the main greenhouse gases which are emitted from pineapple cultivation on peat soils (Chen et al., 2014; Liza, 2014; Jassal et al., 2011; Florides \& Christoudoulides, 2008). Peat soils contain approximately $15 \%$ to $25 \%$ of the terrestrial soil carbon and nitrogen worldwide (Bajtes, 1996). The organic carbon of peat soils undergo natural decomposition, thus causing loss of mass and release by-products such as $\mathrm{CH}_{4}$ and $\mathrm{CO}_{2}$ (Hadi et al., 2005). Carbon in peat soils are lost in the forms of $\mathrm{CH}_{4}$ and $\mathrm{CO}_{2}$. Naturally, these gases are produced under anaerobic and aerobic conditions.

Peatlands as a major carbon sequester arises because greenhouse gases (GHGs) contribute to global warming (Daud, 2009). Tropical peat soils' carbon and GHG balance is determined largely by the net balance between carbon uptake in photosynthesis and carbon release through ecosystem respiration by: (a) vegetation (autotrophic respiration resulting in $\mathrm{CO}_{2}$ emissions from both plant foliage and root systems) and (b) organisms involved in organic matter biological decomposition. In addition, carbon is leached out from the system in drainage runoff as dissolved organic carbon (DOC) or particulate organic carbon (POC) (Moore et al., 2011).

It is important to note that: (a) carbon cycle and GHG processes are highly dynamic and vary at all spatial and temporal scales owing to regional and local variations in macro- and micro-climate and hydrology, as well as localised variations in vegetation and peat decomposition dynamics (Hooijer et al., 2011; Jauhiainen et al., 2005, 2010); and (b) in terms of emissions and global warming potential, $\mathrm{CO}_{2}$ is the most important gas which is emitted from drained peatlands, thus, contributing $98 \%$ or more of the combined global warming potential (GWP) of $\mathrm{CO}_{2}$ and $\mathrm{CH}_{4}$ (Jauhiainen et al., 2011).

Currently, there is limited information on soil $\mathrm{CO}_{2}$ and $\mathrm{CH}_{4}$ emissions from pineapple cultivation on peat soils. According to Couwenberg (2011), $\mathrm{CH}_{4}$ emissions from paddy ecosystem on peat soils are within uncertainty range of the Intergovernmental Panel on Climate Change (IPCC) $\mathrm{CH}_{4}$ default emission factor. Current practices in the measurement of $\mathrm{CO}_{2}$ and $\mathrm{CH}_{4}$ emissions from the surface of peat soils are controversial. Moreover, the emissions of $\mathrm{CO}_{2}$ and $\mathrm{CH}_{4}$ have recently attracted considerable attention because of their contribution to the global climate change. The losses of these gases are also important because soil carbon must be stored for sustainable crop production. In spite of the intensive international research efforts, the newest global $\mathrm{CO}_{2}$ and $\mathrm{CH}_{4}$ balances still have considerable uncertainties in evaluating the specific sources for enhanced $\mathrm{CO}_{2}$ and $\mathrm{CH}_{4}$ (IPCC 1996; Mosier 1996). Uncertainties are because of the variability in soil, and environmental conditions, time, and method used for the measurement of $\mathrm{CO}_{2}$ and $\mathrm{CH}_{4}$ (Mosier 1996; Firestone \& Davidson 1989).

Research findings on $\mathrm{CO}_{2}$ and $\mathrm{CH}_{4}$ emissions in tropical peats which are planted with pineapples are usually controversial due to few or lack of standard information (Ahmed \& Liza, 2015). Greenhouse gas emissions are commonly measured using closed chamber method in a very limited area and time (Zulkefli et al., 2010; Abdul et al., 2005). This leads to inconsistent and sometimes controversial issues which are related to lack of rigid information. Although pineapples are cultivated on tropical peat soils, there is little information on GHG emissions from these soils. The contribution of pineapples cultivation on tropical peat soils to GHG emissions is important. For example, $90 \%$ of pineapples are widely grown on peat soils of Malaysia (Raziah \& Alam, 2010). Kuzyakov (2006) reported that it was important to partition the GHG emissions into respiration components such as microbial and root respirations before deciding on whether peat soils are net sinks or net sources of atmospheric GHG. Failure to account for these GHG losses from drained tropical peatlands could cause underestimation of future rates of increase in atmospheric greenhouse gases and their effects on global environmental change processes (Page et al., 2007).

Based on the foregoing discussion, the objective of this study was to determine the horizontal and vertical emissions of $\mathrm{CO}_{2}$ and $\mathrm{CH}_{4}$, from a tropical peat soil which is cultivated with pineapple (Ananas comosus (L.) Merr. In this study, it was hypothesized that the emissions of $\mathrm{CO}_{2}$ and $\mathrm{CH}_{4}$ into the atmosphere from peat soils under pineapple (Ananas comosus (L.) Merr cultivation are affected by horizontal and vertical transportations. This hypothesis is based on the assumption that the mechanism or mode of transportation of gases causes $\mathrm{CO}_{2}$ and $\mathrm{CH}_{4}$ to be lost to the environment outside or within the soil profile (horizontally and vertically). The results from this study could be used to provide ideas for the appropriate procedures for $\mathrm{CO}_{2}$ and $\mathrm{CH}_{4}$ emissions measurement on a cultivated peat soils. Information obtained from different emissions measurement method will also provide insights on the possible future measures to control $\mathrm{CO}_{2}$ and $\mathrm{CH}_{4}$ emissions from cultivated peat soils. 


\section{Materials and Methods}

\subsection{Experimental Site Description}

This study was carried out at the Malaysia Agricultural Research and Development Institute (MARDI) at Saratok, Sarawak, Malaysia. MARDI, Saratok has an area of 387 hectares and located on a logged-over forest with flat topography of $5 \mathrm{~m}$ to $6 \mathrm{~m}$ above mean sea level (Ahmed \& Liza, 2015). Based on von Post Scale, the peat soil is classified under $\mathrm{H} 7$ to $\mathrm{H} 9$; well decomposed sapric peat with a strong smell and thickness ranging between $0.5 \mathrm{~m}$ and $3.0 \mathrm{~m}$ (Ahmed \& Liza, 2015). The mean temperature of the peat soil area ranges from $22.1{ }^{\circ} \mathrm{C}$ to $31.7{ }^{\circ} \mathrm{C}$ with a relative humidity of $61 \%$ to $98 \%$ (Ahmed \& Liza, 2015). The annual mean rainfall is $3749 \mathrm{~mm}$ but in the wet season, the monthly rainfall is more than $400 \mathrm{~mm}$ whereas in the dry season it is approximately $200.7 \mathrm{~mm}$ (Ahmed \& Liza, 2015).

\subsection{Carbon Dioxide and Methane Emission Measurements}

Horizontal and vertical emissions of $\mathrm{CO}_{2}$ and $\mathrm{CH}_{4}$ were measured from the surface and the walls of the peat soil using different chamber methods. The horizontal emissions of $\mathrm{CO}_{2}$ and $\mathrm{CH}_{4}$ from the surface of the peat soil were measured using I-shaped closed chamber method whereas the vertical emissions of $\mathrm{CO}_{2}$ and $\mathrm{CH}_{4}$ were measured using the L-closed chamber method (Ahmed \& Liza, 2015). The $\mathrm{CO}_{2}$ and $\mathrm{CH}_{4}$ emission measurements were carried out at $0-5 \mathrm{~cm}$ and 5-10 cm peat soil depth, respectively. Measurements of the $\mathrm{CO}_{2}$ and $\mathrm{CH}_{4}$ emission were carried out in $10 \mathrm{~m}$ x $10 \mathrm{~m}$ drained peat soil plots cultivated with pineapple. Carbon dioxide, and $\mathrm{CH}_{4}$, flux sampling was carried out for 24 hours at 6 hours interval (between $0600 \mathrm{hr}$ to $0600 \mathrm{hr}$ ) in dry (July and August) and wet (September and December) seasons.

\subsection{Horizontal Carbon Dioxide and Methane Emission Measurements}

The horizontal emissions of $\mathrm{CO}_{2}$, and $\mathrm{CH}_{4}$ were measured using the closed chamber method (Norman et al., 1997 and Crill, 1991). The fabricated I-shaped chamber was pressed vertically on the surface of the soil pit to a depth of $3 \mathrm{~cm}$ to $5 \mathrm{~cm}$ (Figure 1). The chamber was equilibrated for 30 minutes. Headspace samples of $20 \mathrm{~mL}$ were extracted from the chamber at minute 1 , minute 2 , minute 3 , minute 4 , minute 5 , and minute 6 using a 50 $\mathrm{mL}$ syringe. The extracted gas was then transferred to $20 \mathrm{~mL}$ vacuum headspace vial using a disposable syringe needle. Carbon dioxide and $\mathrm{CH}_{4}$ concentrations were measured using a Gas Chromatography (GC - Agilent 7890A) equipped with thermal conductivity detector (TCD) (Ahmed \& Liza, 2015).

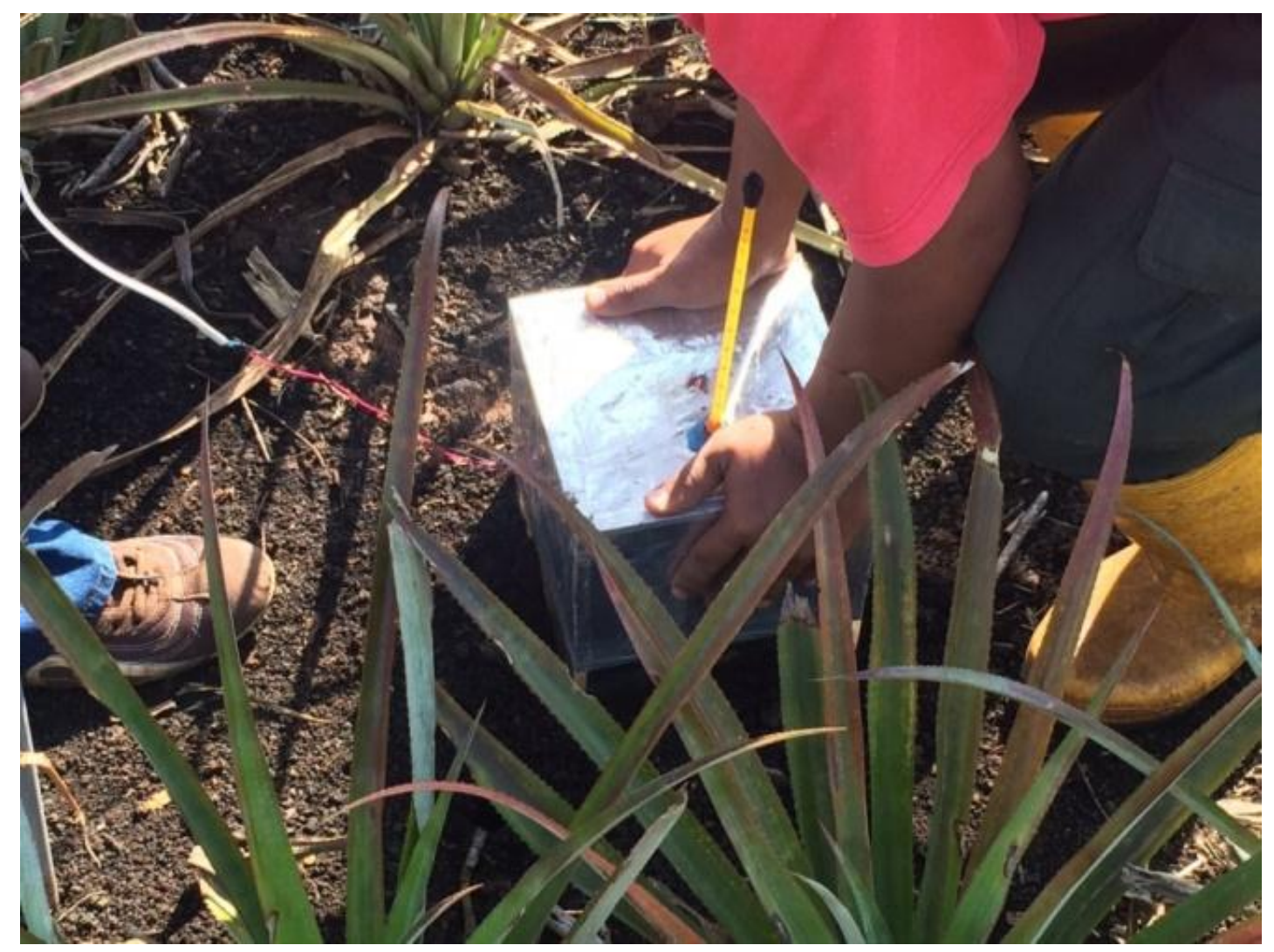

Figure 1. Fabricated I-shaped chamber pressed vertically on the surface of the peat soil pit to a depth of $3-5 \mathrm{~cm}$ 


\subsection{Vertical Carbon Dioxide and Methane Emission Measurements}

The vertical emissions of $\mathrm{CO} 2$ and $\mathrm{CH} 4$ were measured at the walls of the soil pit (10 $\mathrm{cm}$ depth interval), starting from the soil's surface to $10 \mathrm{~cm}$ above the water table (saturated zone). The L-shaped chamber was installed horizontally to the walls of the soil pit to a distance of $20 \mathrm{~cm}$ (Figure 2). For each depth, peat soil was manually scrapped to a suitable working size. The open cylinder was equilibrated for approximately 30 minutes. Headspace sample of $20 \mathrm{~mL}$ was extracted from the chamber at minute 1 , minute 2 , minute 3 , minute 4 , minute 5 , and minute 6 using a $50 \mathrm{~mL}$ syringe. The extracted gas was transferred to $20 \mathrm{~mL}$ vacuum headspace vial using a disposable syringe needle. Carbon dioxide and $\mathrm{CH} 4$ concentrations were measured using Gas Chromatography (GC - Agilent 7890A) equipped with thermal conductivity detector (TCD) (Ahmed \& Liza, 2015).

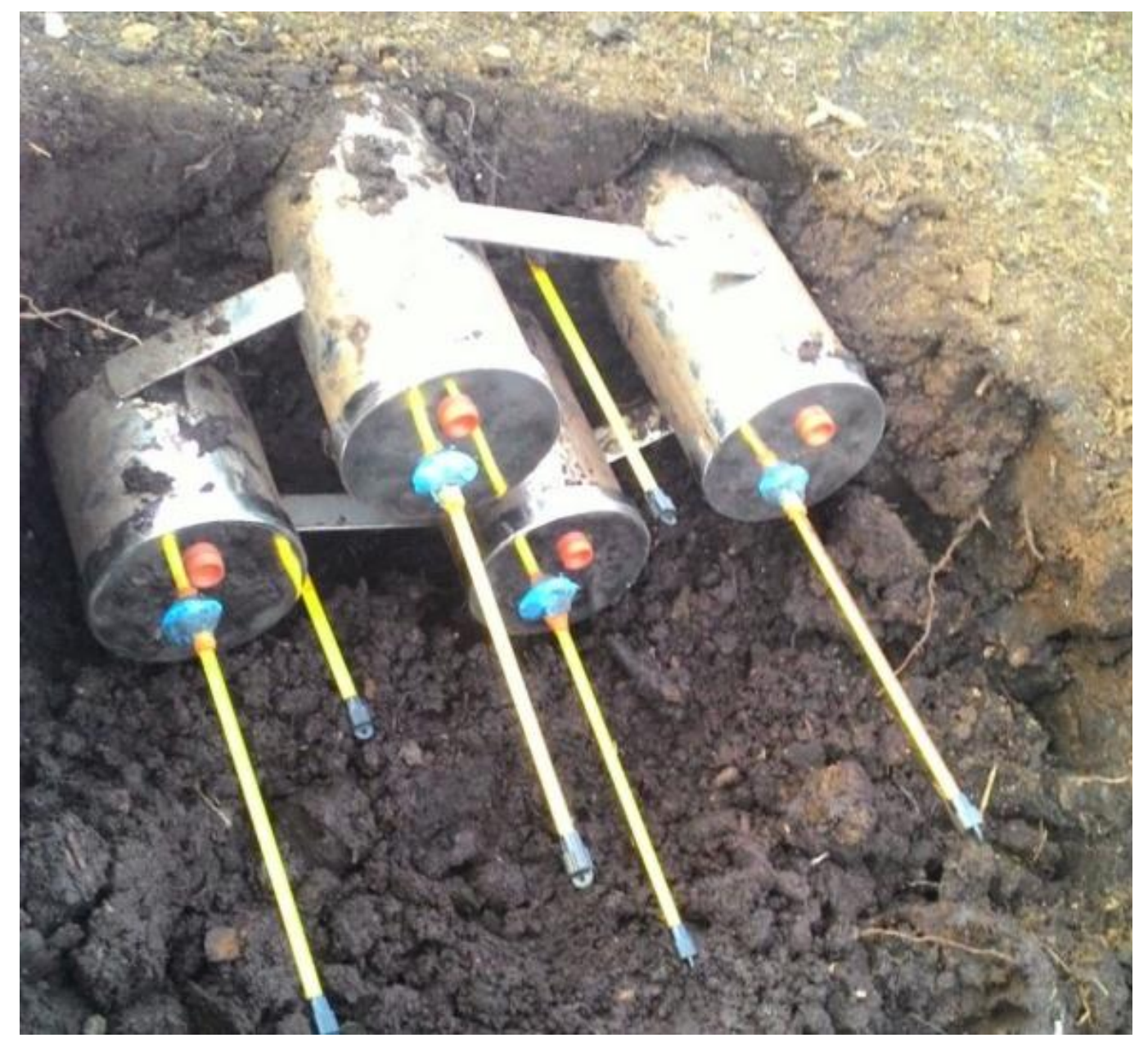

Figure 2. Fabricated L-shaped chamber installed horizontally to the wall of the peat soil pit to a distance of $20 \mathrm{~cm}$

\subsection{Carbon Dioxide and Methane Fluxes Calculation}

The gas flux results were based on the measured $\mathrm{CO}_{2}$ and $\mathrm{CH}_{4}$ from the three replications using different methods (I-chamber and L-chamber) in the dry and wet seasons. The values were averaged and converted to $t$ $\mathrm{ha}^{-1} \mathrm{yr}^{-1}$. The $\mathrm{CO}_{2}$ and $\mathrm{CH}_{4}$ fluxes were then calculated using the following equation (Zulkefli et al., 2010; Widen \& Lindroth, 2003; IAEA, 1992):

$$
\text { Flux }=\left[\left(\mathrm{CO}_{2} / \mathrm{CH}_{4}\right) d t\right] X \text { PVART' }
$$

where $\mathrm{d}\left(\mathrm{CO}_{2} / \mathrm{CH}_{4}\right) /(\mathrm{dt})$ is the evolution rate of $\mathrm{CO}_{2} / \mathrm{CH}_{4}$ within the chamber headspace at a given time after which the chamber were placed into the soil, $\mathrm{P}$ is the atmospheric pressure, $\mathrm{V}$ is the volume headspace gas within the chamber, $\mathrm{A}$ is the area of soil enclosed by the chamber, $\mathrm{R}$ is the gas constant, and $\mathrm{T}$ is the air temperature.

\subsection{Measurements of Peat Soil Temperature}

During gas flux measurement, soil temperature was measured using a portable weather station (WatchDog 2900) 
installed at the study site.

\subsection{Statistical analysis}

Analysis of variance (ANOVA) was used to detect treatment effects whereas treatments means were compared using Tukey's Studentized Range (HSD) Test at $p \leq 0.05$. The relationship between peat soil temperature and gas flux emission was determined using Pearson correlation analysis. The statistical software used for this analysis was Statistical Analysis System (SAS) version 9.3.

\section{Results and Discussion}

\subsection{Horizontal Carbon Dioxide Emission}

Carbon dioxide emission decreased from the early morning I to afternoon after which it increased at midnight and early morning II (Figure 3). The lower $\mathrm{CO}_{2}$ emission was due to the decrease in soil temperature and this caused a decrease in the oxidation of the peat soil. On the other hand, the increase in $\mathrm{CO}_{2}$ emission was the results of increase in soil temperature $\left(25^{\circ} \mathrm{C}\right.$ to $\left.30^{\circ} \mathrm{C}\right)$ as increase in soil temperature favours microbial activities within the soil profile. Studies have shown that $\mathrm{CO}_{2}$ emissions from peat soils relate to soil temperature, as increase in soil temperature increases production of $\mathrm{CO}_{2}$ through decomposition of organic materials (Jauhiainen et al., 2012; Berglund et al., 2010; Kechavarzi et al., 2010; Zulkefli et al., 2010). Furthermore, the increase in $\mathrm{CO}_{2}$ emission might be due to heterotrophic and autothrophic processes in the rhizosphere (Mäkiranta et al., 2008; Kuzyakov, 2006). However, the lowest $\mathrm{CO}_{2}$ emission occurs in the evening when peat soil temperature above optimal temperature $\left(>30^{\circ} \mathrm{C}\right)$ inhibits microbial respiration due to the inactivation of biological oxidation system (Zulkefli et al., 2010, Pietikäinen et al., 2005, Petterson, 2004).

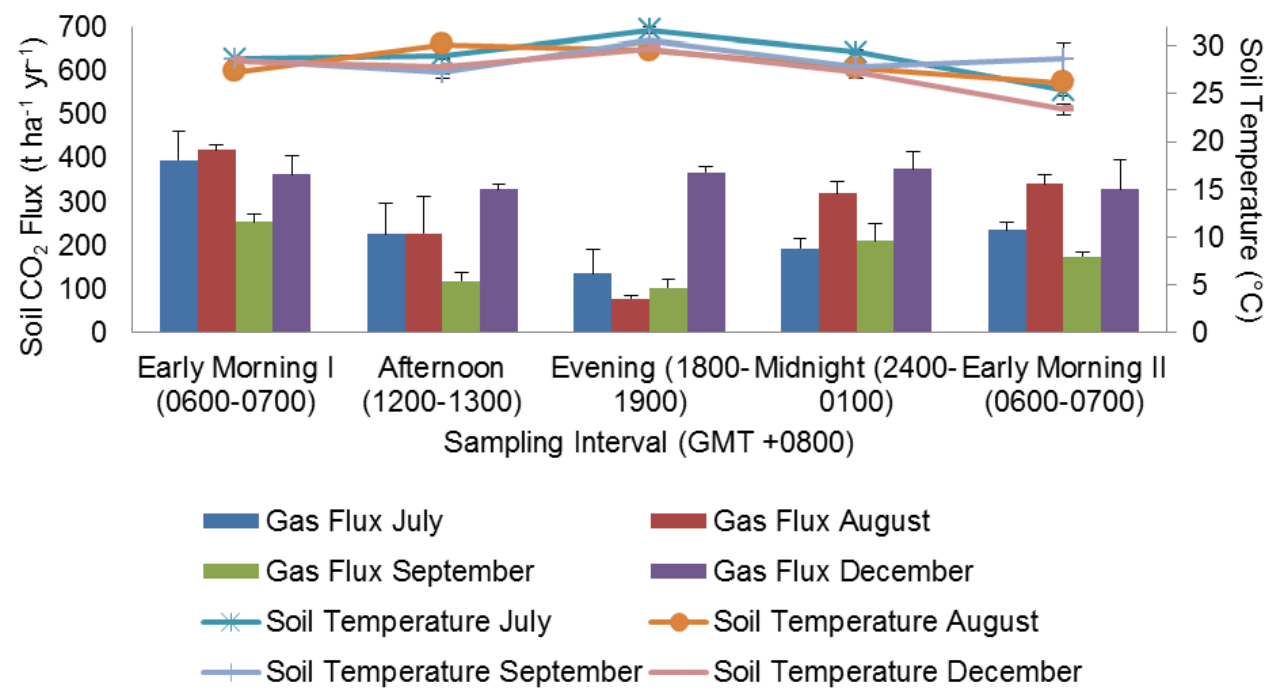

Figure 3. Horizontal emissions of $\mathrm{CO}_{2}$ at different sampling interval and different monitoring period from a tropical peat soil cultivated with pineapple (Error bars represent standard error)

\subsection{Vertical Carbon Dioxide Emission}

In July 2015 and December 2015, the $\mathrm{CO}_{2}$ emission increased from early morning I to evening and thereafter it decreased in the evening till early morning II (Figure 4). The decrease in $\mathrm{CO}_{2}$ was due to heterotrophic respiration was affected by increase in soil temperature (Zulkefli et al., 2010). In September 2015, the decrease in $\mathrm{CO}_{2}$ emission from early morning I to midnight was due to moderate temperature fluctuation from early morning I to midnight (Figure 4). The increase in $\mathrm{CO}_{2}$ emission in the early morning II is related to respiration of the roots of the pineapple plants at 5 months old (Liza, 2014). Furthermore, the increase in $\mathrm{CO}_{2}$ emission in the early morning II might be due to heterotropic respiration in the rhizosphere (Mäkiranta et al., 2008; Kuzyakov, 2006). In August 2015, the $\mathrm{CO}_{2}$ emission decreased from early morning I to afternoon after which it gradually increased in the evening before decreasing at midnight and early morning II (Figure 4) due to soil temperature fluctuations which commonly influence $\mathrm{CO}_{2}$ emission. 

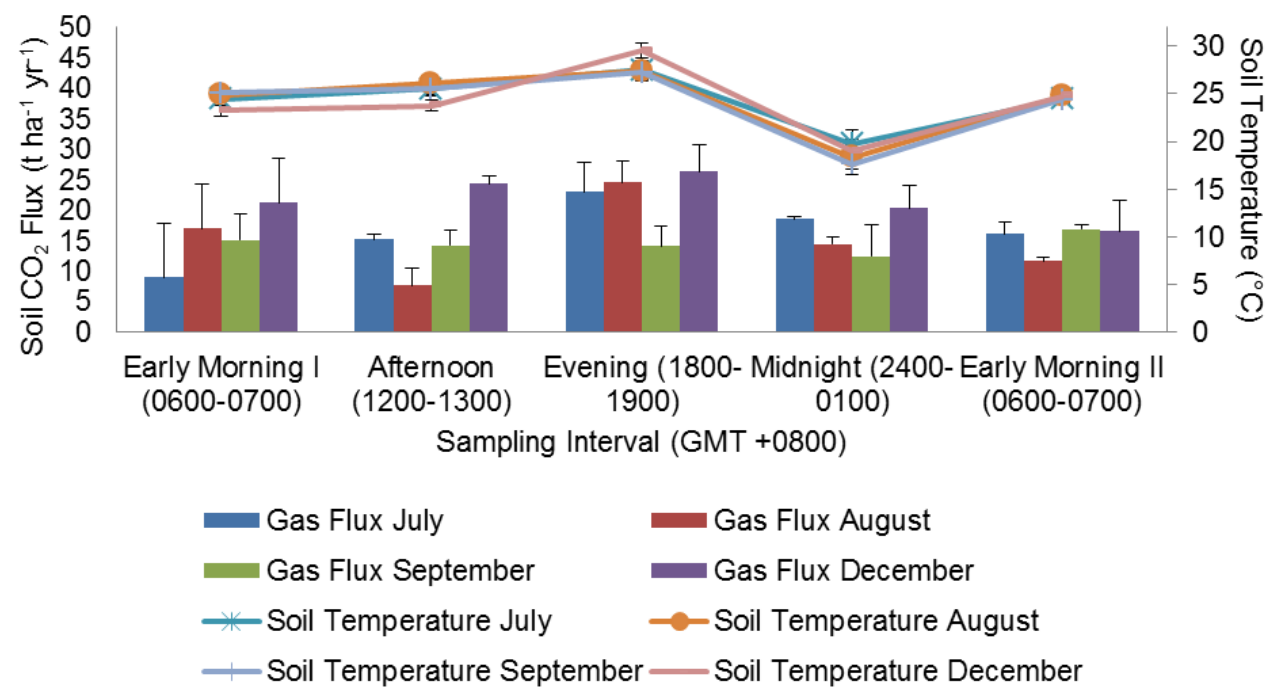

Figure 4. Vertical emissions of $\mathrm{CO}_{2}$ at different sampling interval and different monitoring period from a tropical peat soil cultivated with pineapple (Error bars represent standard error)

\subsection{Summary for Carbon Dioxide Emission}

Between July 2015 and December 2015, there were significant differences in the horizontal emission of $\mathrm{CO}_{2}$ (Figure 5). The highest $\mathrm{CO}_{2}$ emission occurred in December 2015 because of high soil moisture. According to Jauhiainen et al., (2012), in the presence of oxygen, soil moisture above water table affects $\mathrm{CO}_{2}$ emission (Liza, 2014). In August 2015, $\mathrm{CO}_{2}$ emission correlated negatively with soil temperature (Table 1), suggesting that soil temperature causes increases $\mathrm{CO}_{2}$ emission. This relationship is in agreement with the observation in Figure 3 where soil $\mathrm{CO}_{2}$ emission increased with decreasing temperature from midnight to early morning. However, from July 2015 to December $2015, \mathrm{CO}_{2}$ emission did not correlated with soil temperature due to temperature fluctuation across monitoring periods.

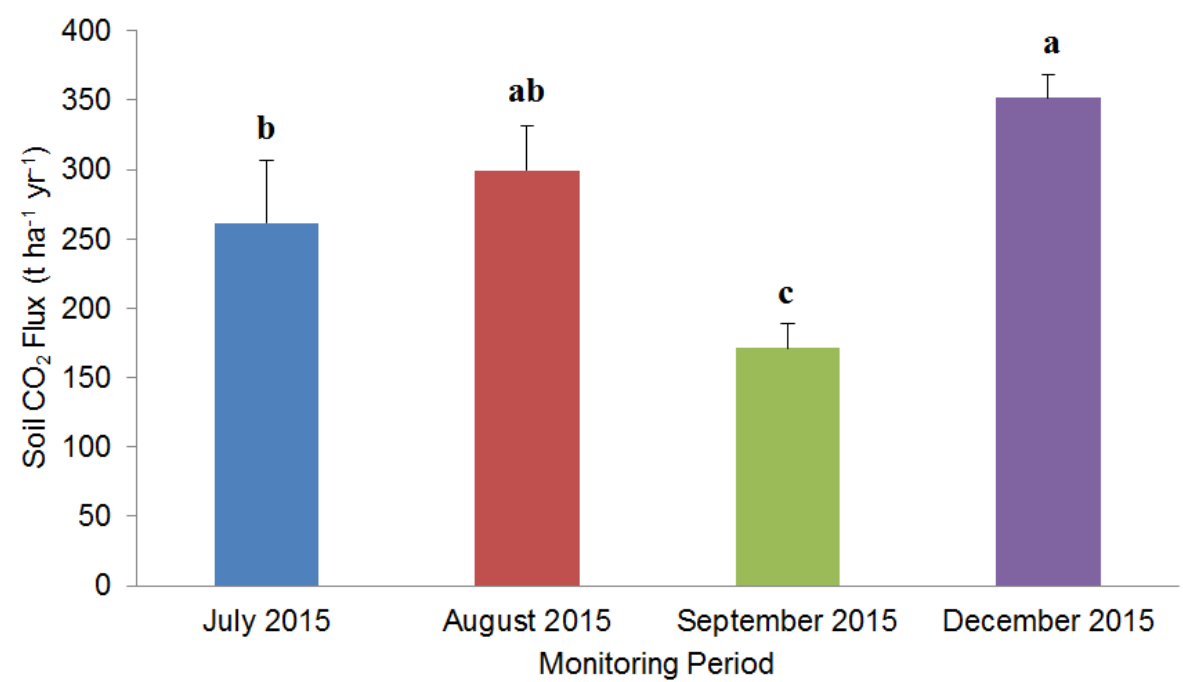

Figure 5. Horizontal emission of carbon dioxide at different monitoring period from a tropical peat soil cultivated with pineapple (Error bars represent standard error and soil mean fluxes with different letters are significantly different at $\mathrm{p} \leq 0.05$ ) 
Table 1. Correlation between horizontal soil carbon dioxide emission and soil temperature of a tropical peat soil

\begin{tabular}{lllll}
\hline & \multicolumn{4}{c}{ Soil Temperature } \\
\cline { 2 - 5 } Month/ Variable & July 2015 & August 2015 & September 2015 & December 2015 \\
Soil CO $\mathrm{C}_{2}$ emission & $-0.13^{\mathrm{ns}}$ & $0.62^{* *}$ & $0.05^{\mathrm{ns}}$ & $0.48^{\mathrm{ns}}$ \\
\hline
\end{tabular}

$* * \mathrm{p} \leq 0.05$

Between August 2015 and December 2015, there were significant differences in vertical $\mathrm{CO}_{2}$ emission (Figure 6). The highest $\mathrm{CO}_{2}$ emission occurred in December 2015 due to high soil moisture (Jauhiainen et al., 2012). From July 2015 to December 2015, there was no correlation between soil $\mathrm{CO}_{2}$ emission and soil temperature (Table 2). These results were consistent with the no significant differences in $\mathrm{CO}_{2}$ emission regardless of time as reported in Figure 6.

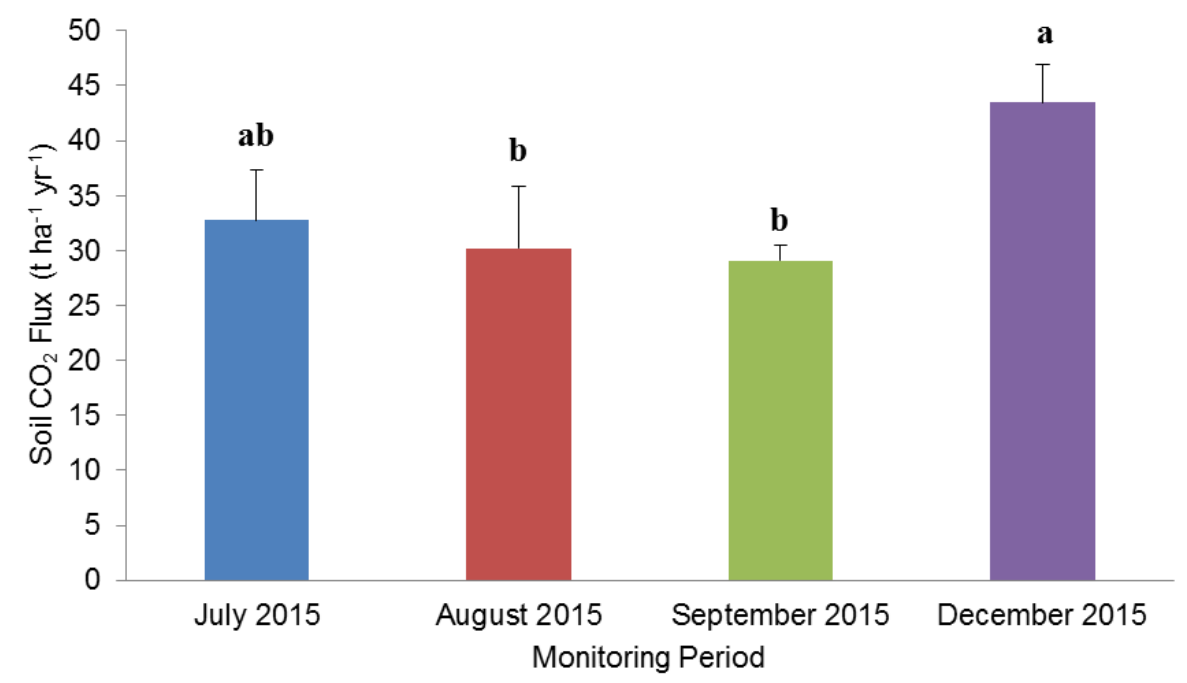

Figure 6. Vertical emission of carbon dioxide at different monitoring period from a tropical peat soil cultivated with pineapple (Error bars represent standard error and soil mean fluxes with different letters are significantly different at $\mathrm{p} \leq 0.05$ )

Table 2. Correlation between vertical soil $\mathrm{CO}_{2}$ emission and soil temperature of a tropical peat soil

\begin{tabular}{lllll}
\hline \multicolumn{5}{c}{ Soil Temperature } \\
\hline Month/ Variable & July 2015 & August 2015 & September 2015 & December 2015 \\
Soil $\mathrm{CO}_{2}$ emission & $-0.02^{\mathrm{ns}}$ & $0.05^{\mathrm{ns}}$ & $-0.29^{\mathrm{ns}}$ & $0.14^{\mathrm{ns}}$ \\
\hline
\end{tabular}

\subsection{Horizontal Methane Emission}

Methane emissions increased in July 2015, August 2015, and September 2015 from early morning I to evening and afterwards, it decreased moderately from evening to early morning II whereas in December $2015, \mathrm{CH}_{4}$ emissions decreased from early morning I to afternoon after which it increased from evening to early morning II (Figure 7). The increase in $\mathrm{CH}_{4}$ emissions might be due to favorable environment and soil temperature. Additionally, the increase in $\mathrm{CH}_{4}$ emissions is related to transportation of $\mathrm{CH}_{4}$ whereby $\mathrm{CH}_{4}$ might have been transported in bubbles through diffusion (Farmer et al., 2011). However, the decrease in $\mathrm{CH}_{4}$ emissions relates to methanogenic bacteria whose activities affect $\mathrm{CH}_{4}$ emissions. Conversion of $\mathrm{CH}_{4}$ to $\mathrm{CO}_{2}$ by methanotrophs at the peat aerobic zone could also be one of the reasons for the reduction in $\mathrm{CH}_{4}$ productions (Liza, 2014). 

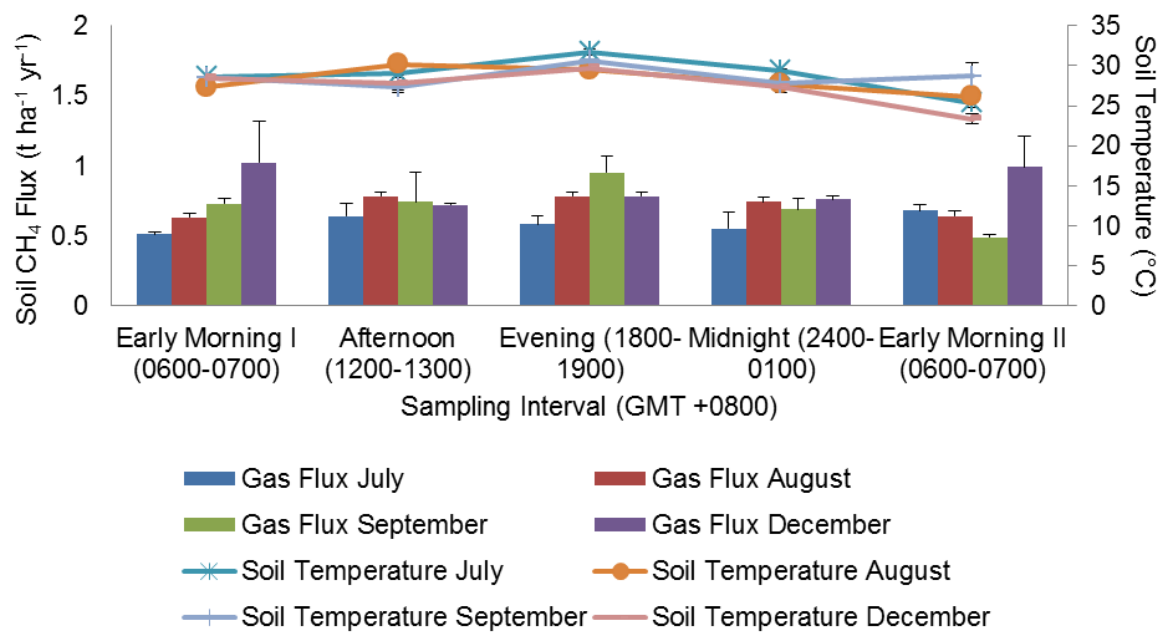

Figure 7. Horizontal emissions of $\mathrm{CH}_{4}$ at different sampling interval and different monitoring period from a tropical peat soil cultivated with pineapple (Error bars represent standard error)

\subsection{Vertical Methane Emission}

There were no significant differences in $\mathrm{CH}_{4}$ emissions across sampling intervals (Figure 8). This trend relates to availability of nitrate (electron acceptors) which inhibits production of $\mathrm{CH}_{4}$ (Sirin \& Laine, 2012; Jassal et al., 2011). Availability of nitrate was due to nitrogen fertilizer application (Liza, 2014). The $\mathrm{CH}_{4}$ emissions were statistically similar irrespective of sampling interval and month of sampling because of the oxidation of $\mathrm{CH}_{4}$ by methanotrophs to $\mathrm{CO}_{2}$ (Parmentier et al., 2009).

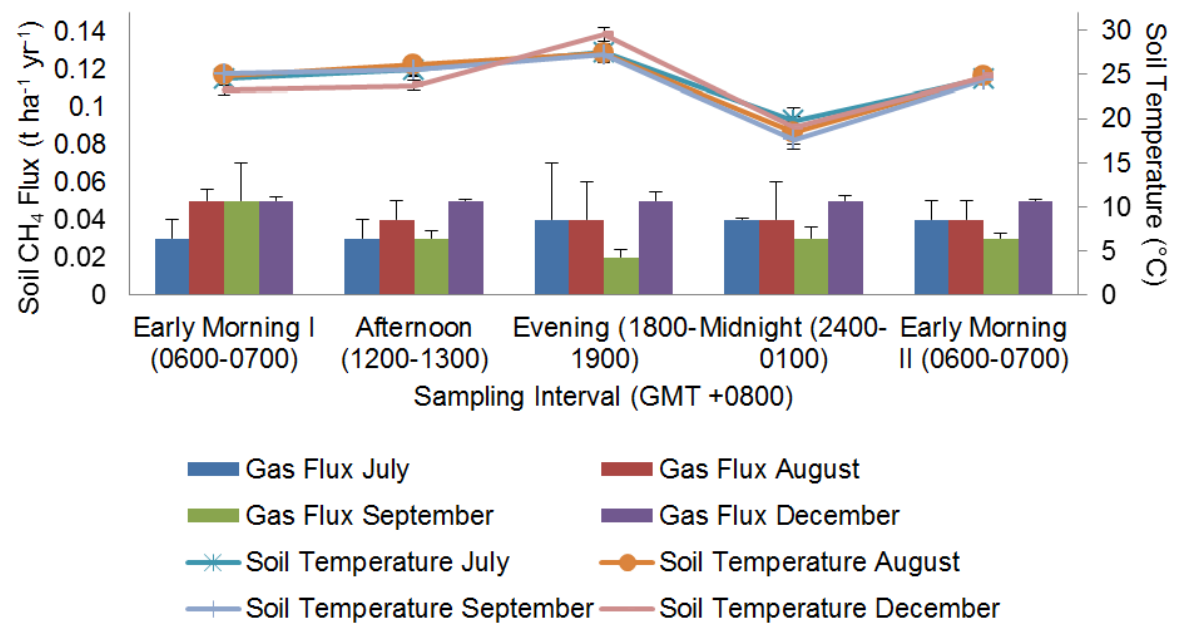

Figure 8. Vertical emissions of $\mathrm{CH}_{4}$ at different sampling interval and different monitoring period from a tropical peat soil cultivated with pineapple (Error bars represent standard error)

\subsection{Summary for Methane Emission}

From July 2015 to December 2015, there were significant differences in $\mathrm{CH}_{4}$ emission (Figure 9). The highest $\mathrm{CH}_{4}$ emission occurred in December 2015 due to high rainfall $(697 \mathrm{~mm})$. This resulted in anaerobic and water logged condition such that it favored emission of $\mathrm{CH}_{4}$. This water logged condition restricted diffusion of atmospheric oxygen and microbial decomposition of organic materials (Chimner \& Cooper, 2003). However, anaerobic degradation of carbon to methanogens- $\mathrm{CH}_{4}$ was possible (Parmentier et al., 2009). From July 2015 to December 2015, there was no correlation between soil $\mathrm{CH}_{4}$ emission and soil temperature (Table 3), suggesting that the factor controlling $\mathrm{CH}_{4}$ emission is related to the fluctuation of water table at the soil-water interface (Sirin \& Laine, 2012). 


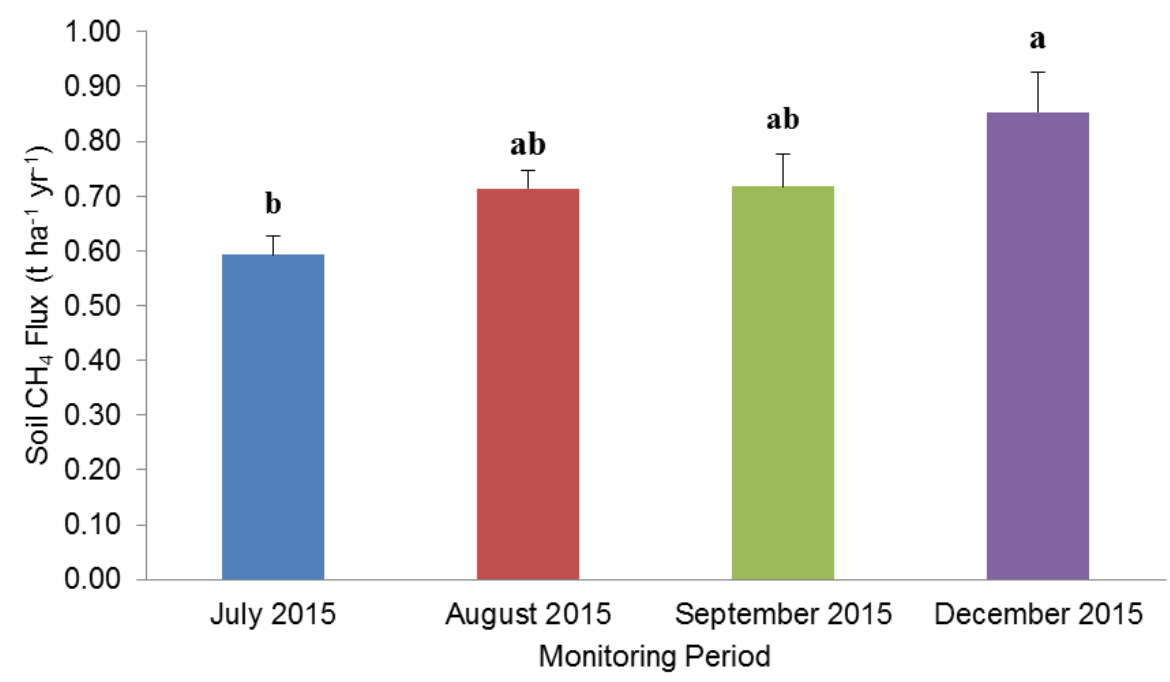

Figure 9. Horizontal emission of methane at different monitoring period from a tropical peat soil cultivated with pineapple (Error bars represent standard error and soil mean fluxes with different letters are significantly different at $\mathrm{p} \leq 0.05)$

Table 3. Correlation between horizontal soil $\mathrm{CH}_{4}$ emission and soil temperature of a tropical peat soil

\begin{tabular}{lllll}
\hline & \multicolumn{5}{c}{ Soil Temperature } \\
\hline Month/ Variable & July 2015 & August 2015 & September 2015 & December 2015 \\
Soil $\mathrm{CH}_{4}$ emission & $-0.44^{\text {ns }}$ & $0.28^{\text {ns }}$ & $0.15^{\text {ns }}$ & $-0.26^{\text {ns }}$ \\
\hline
\end{tabular}

Between August 2015 and December 2015, there were significant differences in vertical $\mathrm{CH}_{4}$ emission (Figure 10). The highest $\mathrm{CH}_{4}$ emission in December 2015 was due to high soil moisture in the top soil above the water table which affects $\mathrm{CH}_{4}$ emission through oxygen availability (Jauhiainen et al., 2012). From July 2015 to December 2015, there was no correlation between soil $\mathrm{CH}_{4}$ emission and soil temperature and this suggests that $\mathrm{CH}_{4}$ emission from the tropical peat under pineapple cultivation is not affected by soil temperature.

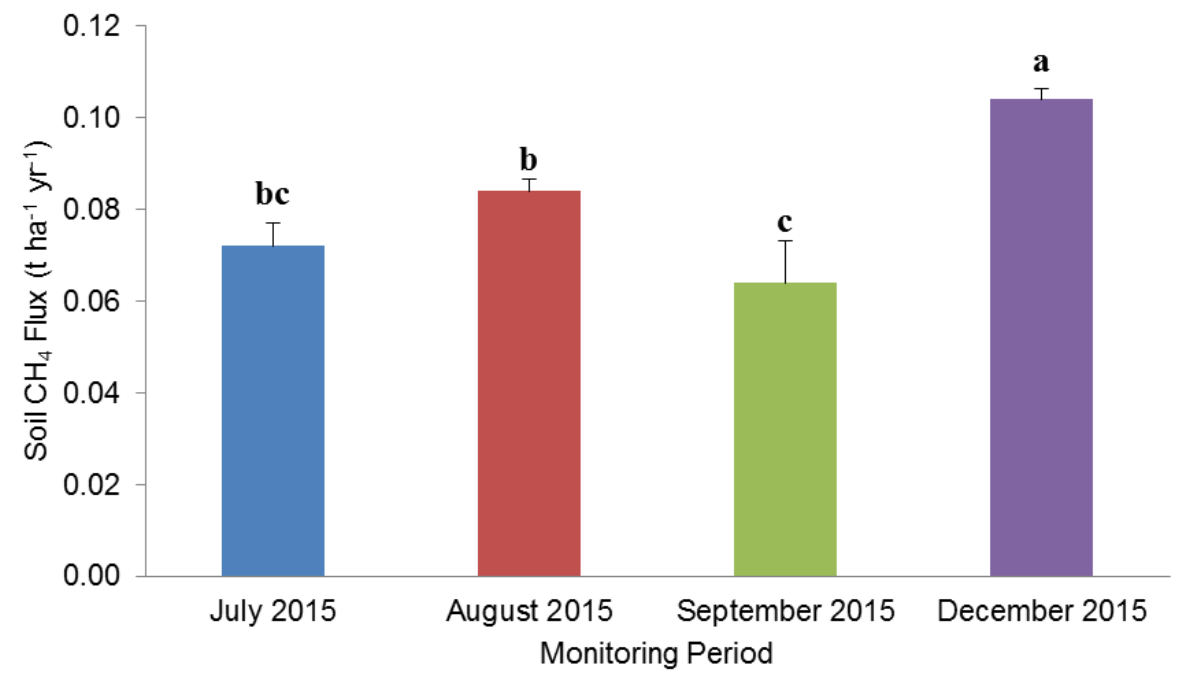

Figure 10. Vertical emission of methane at different monitoring period from a tropical peat soil cultivated with pineapple (Error bars represent standard error and soil mean fluxes with different letters are significantly different at $\mathrm{p} \leq 0.05)$ 
Table 4. Correlation between horizontal methane emission and soil temperature of a tropical peat soil

\begin{tabular}{lllll}
\hline & \multicolumn{5}{c}{ Soil Temperature } \\
\hline Month/ Variable & July 2015 & August 2015 & September 2015 & December 2015 \\
Soil $\mathrm{CH}_{4}$ emission & $0.19^{\mathrm{ns}}$ & $0.27^{\mathrm{ns}}$ & $0.22^{\mathrm{ns}}$ & $0.01^{\mathrm{ns}}$ \\
\hline
\end{tabular}

\section{Conclusion}

The horizontal soil $\mathrm{CO}_{2}$ emission was higher in the dry season than in the wet season due to the high carbon content of the peat soil. The vertical soil $\mathrm{CO}_{2}$ emission was higher in the wet season than in the dry season due to higher rainfall during the wet season.

The horizontal soil $\mathrm{CH}_{4}$ emission was higher than in the wet season due to the increase in water table which resulted in increase of $\mathrm{CH}_{4}$ emission. The vertical soil $\mathrm{CH}_{4}$ emission was higher in the wet season than in the dry season because of favourable condition essential for methanogenesis as methanogenesis increases oxidation of $\mathrm{CH}_{4}$.

Soil $\mathrm{CO}_{2}$ emission was higher compared with $\mathrm{CH}_{4}$ regardless of the differences in diurnal transportation and mode of transportation (horizontal or vertical transportation of $\mathrm{CO}_{2}$ and $\mathrm{CH}_{4}$ ). With respect to the nature of transportation, horizontal transportation contributed $70.84 \%$ of $\mathrm{CO}_{2}$ and $0.19 \% \mathrm{CH}_{4}$ emissions whereas vertical transportation contributed $8.85 \%$ of $\mathrm{CO}_{2}$, and $0.02 \% \mathrm{CH}_{4}$ emissions. Therefore, it can be concluded that $\mathrm{CO}_{2}$ and $\mathrm{CH}_{4}$ emissions occur horizontally and vertically regardless of season and time of the day. In order not to underestimate $\mathrm{CO}_{2}$ and $\mathrm{CH}_{4}$ emissions from peat soils, it is important to measure the emissions of these greenhouse gases horizontally and vertically.

\section{Acknowledgements}

Our appreciation goes to the Ministry of Higher Education, Malaysia, and Universiti Putra Malaysia for the financial support provided through Putra Grant and Fundamental Research Grant Scheme (FRGS - 5524983) and (Project FRGS/1/2015/WAB01/MOA/02/2). We would like to thank Malaysia Agricultural Research and Development Institute (MARDI) Saratok, Sarawak, Malaysia for the collaborative research.

\section{References}

Abdul, H., Kazuyuku, I., Yuichiro, F., Erry, P., Muhammad, R., \& Haruo, T. (2005). Greenhouse Gas Emissions from Tropical Peatlands of Kalimantan, Indonesia. Nutrient Cycling in Agrosystems, 71, 73-80.

Ahmed, O. H., \& Liza, N. L. K. C. (2015). Greenhouse Gas Emission \& Carbon Leaching in Pineapple Cultivation on Tropical Peat Soil. Serdang: Universiti Putra Malaysia Press.

Berglund, Ö., \& Berglund, K. (2011). Influence of Water Table Level and Soil Properties on Emissions of Greenhouse Gases from Cultivated Peat Soil. Soil Biology \& Biochemistry, 43, 923-931. https://doi.org/10.1016/j.soilbio.2011.01.002

Berglund, Ö., Berglund, K., \& Klemedtsson, L. (2010). A Lysimeter Study on the Effect of Temperature on $\mathrm{CO}_{2}$ Emission from Cultivated Peat Soils. Geoderma, 154(3-4), 211-218. https://doi.org/10.1016/j.geoderma.2008.09.007

Chimner, R. A., \& Cooper, D. J. (2003). Influence of Water Table Levels on $\mathrm{CO}_{2}$ Emissions in a Colorado Subalpine Fen: an in situ microcosm study. Soil Biology \& Biochemistry, 35, 345-351. https://doi.org/10.1016/S0038-0717(02)00284-5

Crill, P. M. (1991). Seasonal Patterns of Methane Uptake and Carbon Dioxide Release by a Temperate Woodland Soil. Global Biogeochem. Cyc., 5, 319-334. https://doi.org/10.1029/91GB02466

Hoojier, A., Page, S., Canadell, J. G., Silvius, M., Kwadijk, J., Wösten, H., \& Jauhiainen, J. (2010). Current and Future $\mathrm{CO}_{2}$ Emissions from Drained Peatlands in Southeast Asia. Biogeoscience, 7, 1505-1514. https://doi.org/10.5194/bg-7-1505-2010

IAEA. (1992). Manual on Measurement of Methane and Nitrous Oxide Emissions from Agriculture. In Sampling Techniques and Sampling Handling. pp. 45-67 IAEA-TECDOC-674. Vienna, Austria: IAEA.

Ismail, A. B. (2010). Farm Management Practices for Mitigation of Carbon Dioxide Emission in Peatland Agrosystems. In Proceedings of the International Conference on Balanced Nutrient Management for Tropical Agriculture (pp. 72-76). Kuantan, Pahang. 
Jassal, R. S., Black, T. A., Roy, R., \& Ethier, G. (2011). Effect of Nitrogen Fertilization on Soil $\mathrm{CH}_{4}$ and $\mathrm{N}_{2} \mathrm{O}$ Fluxes, and Soil and Bole Respiration. Geoderma, 162, 182-186. https://doi.org/10.1016/j.geoderma.2011.02.002

Jauhiainen, J., Hoojier, A., \& Page, S. E. (2012). Carbon Dioxide Emissions from an Acacia Plantation on Peatland in Sumatra, Indonesia. Biogeoscience, 9, 617-630. https://doi.org/10.5194/bg-9-617-2012

Kechavarzi, C., Dawson, Q., Bartlett, M., \& Leeds-Harrison, P.B. (2010). The Role of Soil Moisture, Temperature and Nutrient Amendment on $\mathrm{CO}_{2}$ Efflux from Agricultural Peat Soil Microcosms. Geoderma, 154, 203-210. https://doi.org/10.1016/j.geoderma.2009.02.018

Kuzyakov, Y. (2006). Sources of $\mathrm{CO}_{2}$ Efflux from Soil and Review of Partitioning Methods. Soil Biology \& Biochemistry, 38, 425-448. https://doi.org/10.1016/j.soilbio.2005.08.020

Kuzyakov, Y., \& Larionova, A.A. (2006). Contribution of Rhizomicrobial and Root Respiration to the $\mathrm{CO}_{2}$ Emission from Soil (A Review). Eurasian Soil Science, 39(7), 753-764.

Liza, N. L. K. C. (2014). Greenhouse Gas Emission Partitioning and Carbon Leaching in Drained Tropical Peatland, Saratok, Sarawak, Malaysia. Ph.D. dissertation, Universiti Putra Malaysia.

Mäkiranta, P., Minkkinen, K., Hytönen, J., \& Laine, J. (2008). Factors causing Temporal and Spatial Variation in Heterotropic and Rhizospheric components of Soil Respiration in Afforested Organic Soil Croplands in Finland. Soil Biology \& Biochemistry, 40, 1592-1600. https://doi.org/10.1016/j.soilbio.2008.01.009

Norman, J. M., Kucharik, C. J., Gower, S. T., Baldocchi, D. D., Crill, P. M., Rayment, M., Savage, K., \& Striegl, R. G. (1997). A Comparison of Six Methods for Measuring Soil- Surface Carbon Dioxide Fluxes. Journal of Geophysical Research, 102, 28771-28777. https://doi.org/10.1029/97JD01440

Parmentier, F. J. W, van der Molen, M. K., de Jeu, R. A. M., Hendriks, D. M. D., \& Dolman, A. J. (2009). $\mathrm{CO}_{2}$ Fluxes and Evaporation on a Peatland in the Netherlands appear not affected by Water Table Fluctuations. Agricultural and Forest Meteorology, 149, 1201-1208. https://doi.org/10.1016/j.agrformet.2008.11.007

Petterson, M. (2004). Factors Affecting Rates of Change in Soil Bacterial Communities. Ph.D. dissertation, Lund University, Sweden. Retrieved from http://www.lub.lu.se/luft/diss/sci_649/sci_649.pdf

Pietikäinen, J., Petterson, M., \& Bääth, E. (2005). Comparison of Temperature Effects on Soil Respration and Bacterial and Fungal Growth Rates. FEMS Microbial Ecology, 52(1), 49-58. https://doi.org/10.1016/j.femsec.2004.10.002

Wid'en, B., \& Lindroth, A. (92003). A Calibration System for Soil Carbon Dioxide-Efflux Measurement Chambers. Soil Science Society of America Journal, 67, 327-334. https://doi.org/10.2136/sssaj2003.3270

Zulkefli, M., Liza, N. L. K. C., \& Ismail, A. B. (2010). Soil $\mathrm{CO}_{2}$ Flux from Tropical Peatland under Different Land Clearing Techniques. Journal of Tropical Agriculture and Food Science, 38(1), 131-137.

Zulkefli, M., Liza, N. L. K. C., Ismail, A. B., \& Jamaludin, J. (2008). Soil Carbon Loss under Different Land Clearing Techniques and Agriculture Systems on Tropical Peatland. In Proceedings of the International Symposium and Workshop on Tropical Peatland: Peat Development - Wise Use and Impact Management (pp. 376-381). Kuching, Sarawak, Malaysia.

\section{Copyrights}

Copyright for this article is retained by the author(s), with first publication rights granted to the journal.

This is an open-access article distributed under the terms and conditions of the Creative Commons Attribution license (http://creativecommons.org/licenses/by/3.0/). 